Moses and Multiculturalism 


\section{FLASHPOINTS}

The series solicits books that consider literature beyond strictly national and disciplinary frameworks, distinguished both by their historical grounding and their theoretical and conceptual strength. We seek studies that engage theory without losing touch with history, and work historically without falling into uncritical positivism. FlashPoints will aim for a broad audience within the humanities and the social sciences concerned with moments of cultural emergence and transformation. In a Benjaminian mode, FlashPoints is interested in how literature contributes to forming new constellations of culture and history, and in how such formations function critically and politically in the present. Available online at http://repositories .cdlib.org/ucpress

\section{SERIES EDITORS}

Fudith Butler, Edward Dimendberg, Catherine Gallagher, Susan Gillman Richard Terdiman, Chair

1. On Pain of Speech: Fantasies of the First Order and the Literary Rant, by Dina Al-Kassim

2. Moses and Multiculturalism, by Barbara Johnson 


\title{
Moses and Multiculturalism
}

\author{
Barbara Johnson
}

Foreword by Barbara Rietveld

甲

UNIVERSITY OF CALIFORNIA PRESS

Berkeley Los Angeles London 
University of California Press, one of the most distinguished university presses in the United States, enriches lives around the world by advancing scholarship in the humanities, social sciences, and natural sciences. Its activities are supported by the UC Press Foundation and by philanthropic contributions from individuals and institutions. For more information, visit www.ucpress.edu.

University of California Press

Berkeley and Los Angeles, California

University of California Press, Ltd.

London, England

C 2010 by The Regents of the University of California

Library of Congress Cataloging-in-Publication Data

Johnson, Barbara, 1947-2009.

Moses and multiculturalism / Barbara Johnson ; foreword by Barbara Rietveld.

p. cm.-(Flashpoints, 2)

Includes bibliographical references and index.

ISBN 978-0-520-26254-6 (pbk. : alk. paper)

I. Moses (Biblical leader). 2. Multiculturalism. I. Title.

BS580.M6J64 2010

222 '.1092- $\mathrm{dc2} 2$

2009019422

Manufactured in the United States of America

$\begin{array}{llllllllll}\text { I9 } & \text { I8 } & \text { I7 } & \text { I6 } & \text { I5 } & \text { I4 } & \text { I3 } & \text { I2 } & \text { II } & \text { IO }\end{array}$

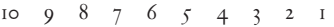

The paper used in this publication meets the minimum requirements of ANSI/NISO Z39.48-I992 (R 1997)

(Permanence of Paper). 
To Shoshana Felman 
This page intentionally left blank 